\title{
STRATEGIES OF TOURISM SERVICE PROVIDERS TO COPE WITH THE COVID-19 PANDEMIC
}

\author{
Helena KUBÍČKOVÁa, Andrea HOLEŠINSKÁa \\ a Masaryk University, Faculty of Economics and Administration, Brno, Czech Republic, \\ helena.kubickova@mail.muni.cz; holesinska@econ.muni.cz
}

Cite this article: Kubíčková, H., Holešinská, A. (2021). Strategies of Tourism Service Providers to Cope with the COVID-19 Pandemic. Deturope. 13(3), 118-129.

\begin{abstract}
The situation with the COVID-19 pandemic has a negative impact on the development of tourism. It imposes restrictions on both tourism supply and tourism demand. Government lockdowns travel businesses and, at the same time, restricts the freedom of movement. Thus, the supply and demand sides have to cope with the exogenous shocks. The first evidence of experience and reactions of travel businesses was presented in early March 2020. Data from bookings describes how visitors start to adapt their travel behavior to the exit strategies. Even rural tourism is affected by the worldwide spread crisis. To highlight the impacts on rural tourism, this research focuses on middle and small-sized entrepreneurs (e.g., farmers, winemakers, local private rural museums, local accommodation providers; local providers of hippotherapy) and on local tourist organizations (e. g. DMO, tourist information centers) involved in rural tourism. The aim of this study is to show how they overcame the situation with the COVID-19 pandemic. In other words, the study describes the changes in visitor behavior from the perspective of rural tourism providers. The research is based on a case study of South Moravia and applies both qualitative (a questionnaire survey) and quantitative (interviews) methods. The research data shows that rural tourism providers manage to cope with the government restrictions and tailor their services to new customers" requirements as well. Besides the loss of incomes, tourism service providers face a decrease in the number of visitors, and thus they suffer a slump in sales. The majority of all rural tourism providers responded that their segment of visitors had changed. More specifically, the absence of foreign visitors was replaced by domestic ones.
\end{abstract}

Keywords: COVID-19; behavior of visitors; reactions of service providers; exit strategy; rural tourism

\section{INTRODUCTION}

Undoubtedly, the COVID-19 pandemic is the biggest issue nowadays. The effects of the COVID-19 pandemic on international tourism (e.g., Gössling, Scott \& Hall, 2021) and its transformation impacts (e.g., Hall, Scott, \& Gössling, 2021) have been extensively published. Even estimating models (Škare, Sariano, \& Porada-Rochoń, 2021) have been introduced. In general, the impacts on tourism businesses have been widely discussed (e.g., Richards, 2020), as well as the behaviour of the tourism demand-side (e.g., Keller, 2020).

The aim of this paper is to identify exit strategies of tourism service providers (from both the private and public sectors) that helped them to overcome the situation with the COVID-19 pandemic. The paper highlights two aspects that influence the behavior of tourism service 
providers during the COVID-19 pandemic. The first one considers the government restrictions and the second one the visitors' changed decisions.

Furthermore, the paper describes the application of crisis management in tourism practice. Tourism service providers (specifically, small-sized entrepreneurs) without any previous experience had to cope with the situation and had to invent their own strategy how to survive.

\section{THEORETICAL BACKGROUND}

Knowledge of the behavior (expectations) of visitors is important for the decision-making of tourism service providers. Based on this knowledge, they can effectively make their offer (tourism product). The behavior of visitors and their motives have been addressed by a number of authors. In the 1960s-1970s, it was a trend to travel with the motive of "recovering from work" and the possibilities and availability of travel had an impact on the decision-making that appeared differently for certain groups of people, see Cohen (1972) and his typology of the visitor or Plog (1973) and his classification of alo-centric and psychocentric. In the 1990s, travel became a 'philosophy of life' and this was reflected in the changes of visitor behavior, see posttourist (Urry, 1990). Information and communication technologies are bringing a major change in the trend of visitor behavior. The instant availability of information and at the same time the easy accessibility to the destination result in the fact that the visitor makes decisions very quickly (Tajeddini, Ratten, Merkle, 2019) and spends his/her holiday in the same way. The vacation is cheaper, shorter and faster (Poon, 2003). However, a dramatic change was brought about by the COVID-19 pandemic, which slowed down this trend (Fotiadis, Polyzos, Huan, 2021). Visitors were forced to reevaluate their expectations (Hao, Bai, Sun, 2021). Nevertheless, the desire to travel has remained! In addition, visitor attitudes and requirements have changed (www.revfine.com, 2020). Digital technologies dominate the tourism industry. People want to travel safely! (Kock, Nørfelt, Josiassen, Assaf Tsionas, 2020) But they prefer local experiences - avoiding mass tourism as a potential opportunity to get infected with COVID-19. Moreover, they choose nearby destinations rather than international ones (Arbulú, Razumova, Rey-Maquieira, Sastre, 2021). The first research question in this context is: How did visitors adapt their behavior to the situation with the COVID-19 pandemic?

However, changes in visitor behavior are not the only aspect to which tourism service providers must adapt. The corona pandemic as an exogenous shock precedes a crisis situation (Keller, 2020), to which governments must urgently respond. The search for decisions and unclear communication from the government creates instability and chaos (Holešinská \& 
Záboj, 2021). The crisis becomes chronic under these conditions (Antušák, 2009). Tourism service providers are thus forced to develop a strategy that will meet the demands of visitors and at the same time comply with government restrictions. The further research questions are: How did tourism service providers cope with government restrictions? How did they react to the visitor's changed behavior?

\section{DATA AND METHODS}

For the purpose of this research, the case study was chosen as the best example demonstrating the behaviour of tourism service providers with the beginning of the COVID-19 pandemic (spring 2020). The basis is a questionnaire survey. This was supplemented by personal interviews. The case study is, therefore, both quantitative and primarily qualitative in nature.

The questionnaire included both closed and open-ended questions or combined questions. The structure of the questionnaire corresponded to the focus of the research. The questionnaire was distributed by email, in the form of a link to the online application, and at the same time in the form of .doc or .pdf format.

As far as the interviews are concerned, they were conducted, both in person and by telephone due to the COVID-19 pandemic. Representatives who provide typical services of rural tourism from both public and private sector were selected.

\section{Data sample}

The research included 823 entities. These represented typical service providers of rural tourism. The major criterium was the local character of their service. A total of 121 respondents answered the questionnaire survey, which ran from May to July 2021 (Tab. 1). Of these, tourism service providers from the private sector are dominant. The return rate of the questionnaires was $14 \%$. The lower return rate can be attributed to a reluctance to respond due to the long duration of the COVID-19 pandemic and partly due to the number of open-ended questions. Nevertheless, valuable information was still obtained and supported by the interviews conducted. Two business entities and one public sector entity participated in the interviews.

Table 1 Data sample

\begin{tabular}{|c|c|c|c|c|}
\hline Total addressed & \multicolumn{2}{|c|}{ Respondents $(\mathrm{n}=121)$} & \multicolumn{2}{|c|}{ Interviews $(n=3)$} \\
\hline \multirow[t]{2}{*}{823} & Private & Public & Private & Public \\
\hline & 95 & 26 & 2 & 1 \\
\hline
\end{tabular}

Source: own survey 
The case study covers the region of South Moravia in the Czech Republic. The destination is typical of its rural character. In addition, the destination is famous for its leisure activities, such as wine tourism, farming, or cycling. Besides the providers of typical business services, such as private accommodation, wine degustation, farming, bike rent, boat rent, and wellness, the research sample covers the providers of public services, e.g., tourist information centres, nature and culture heritage, museums, destination management organizations (DMOs). Providers were categorised according to their specialization into eight categories (Tab. 2).

Table 2 Categories of tourism service providers and their representation in the data sample

\begin{tabular}{|l|l|l|l|l|l|l|}
\hline Categories & $\begin{array}{l}\text { Private } \\
\text { Sector }\end{array}$ & $\%$ & $\begin{array}{l}\text { Public } \\
\text { Sector }\end{array}$ & $\%$ & Total & $\%$ \\
\hline Accommodation & 64 & 52.9 & 1 & 0.9 & 65 & 53.8 \\
\hline Wine tourism & 18 & 14.9 & 0 & 0.0 & 18 & 14.9 \\
\hline Cycling tourism & 5 & 4.1 & 0 & 0.0 & 5 & 4.1 \\
\hline Agritourism & 4 & 3.3 & 0 & 0.0 & 4 & 3.3 \\
\hline Attractiveness \& Services & 4 & 3.3 & 4 & 3.3 & 8 & 6.6 \\
\hline Historical \& Natural Heritage & 0 & 0.0 & 4 & 3.3 & 4 & 3.3 \\
\hline Tourist centers & 0 & 0.0 & 13 & 10.7 & 13 & 10.7 \\
\hline DMOs & 0 & 0.0 & 4 & 3.3 & 4 & 3.3 \\
\hline Total & 95 & 78.5 & 26 & 21.5 & 121 & 100.0 \\
\hline
\end{tabular}

Source: own research

The composition of employees in the sample is mainly represented by family businesses and small-sized entrepreneurs, which confirms the rural character of the region. Prior to the coronacrisis, $32 \%$ of respondents had no (0) employees. $46 \%$ of respondents had $1-5$ employees. $13 \%$ of respondents reported employing 6-10 people. And only $12 \%$ of tourism service providers had more than ten employees.

\section{Methods}

The data obtained were cleaned and processed using mathematical and statistical methods. Due to the nature of the questions, mainly descriptive statistics was used. The responses from the open-ended questions of the questionnaire and the interview outputs, which are qualitative in nature, were subjected to sentiment analysis and categorized according to commonalities. A word cloud method was also used to visualize the most frequent statements of respondents.

The key output presenting the categorized views of respondents is the matrix of change. The matrix is based on the frequencies of the statements, which are then compared. The matrix 
represents a system that describes the association between the changes in visitor behavior (tourism demand side) and reactions of tourism service providers to the changes in customer requirements (tourism supply-side).

\section{RESULTS}

Overall, tourism service providers commented on the impact of the COVID-crisis on their business (Fig. 1). Based on the Likert-scale, respondents assessed their situation. For the purpose of this paper, the results assessed the Change in number of visitors, Change in customer base, and Change/adaptation to customer requirements - see the box.

Figure 1 Impact of the COVID-19 pandemic on tourism service providers

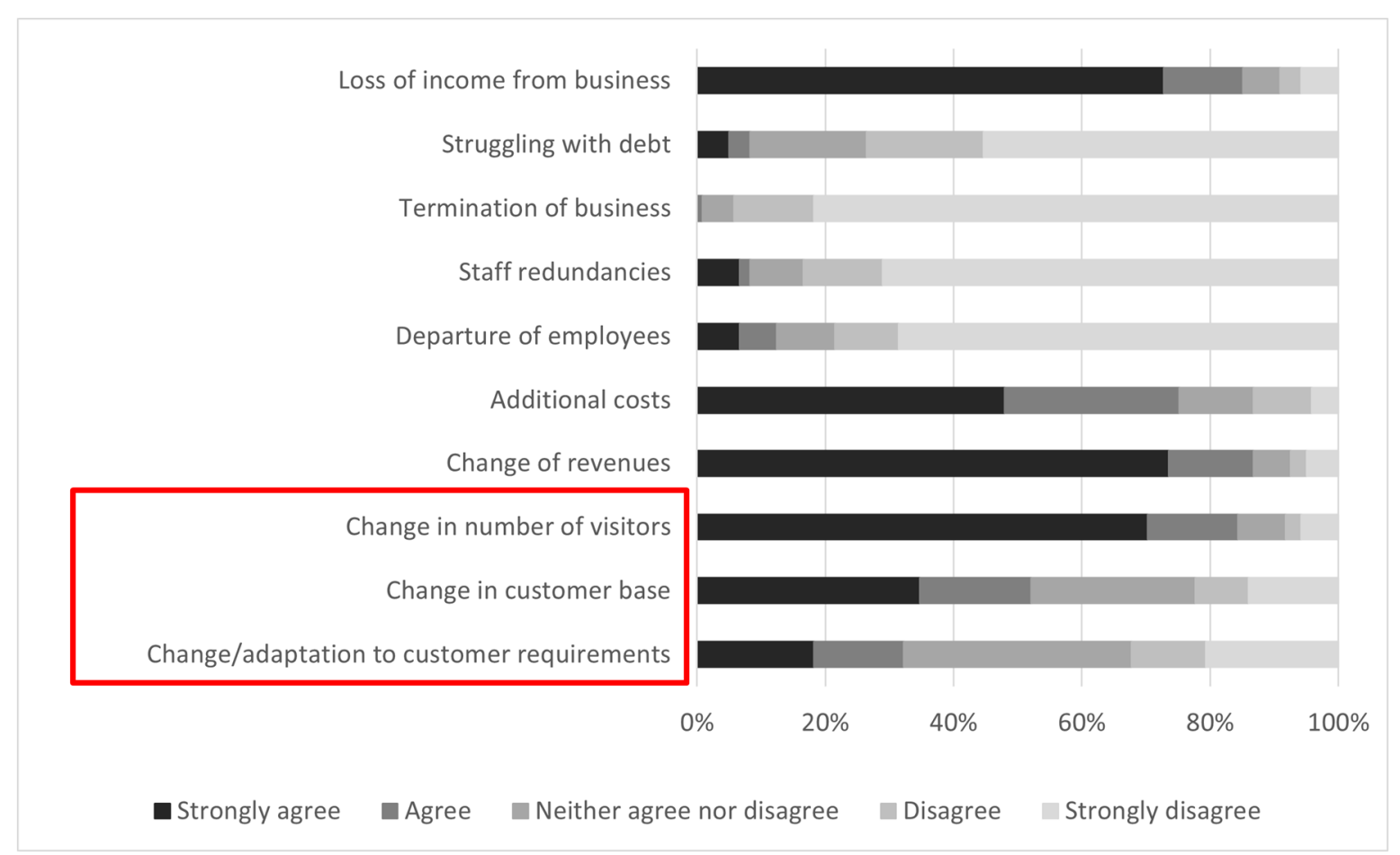

Source: own survey

However, additional comments from respondents $(n=28)$ revealed other relevant responses that further specified not only a change in the behavior of some tourism service providers, but also a change in the behavior of visitors. In the case of tourism service providers, this was an attempt to optimize their activities by adjusting their offer. In the second case, it was about specific changes in visitor behavior. 


\section{Visitor behavior in the COVID-19 pandemic}

The results show that the majority of respondents $(86 \%, \mathrm{n}=121)$ experienced a significant decrease in the number of visitors compared to the pre-pandemic status. The decrease ranged from $26-50 \%$. This was mainly due to the government restrictions in the form of state border closures (movement restrictions) and lockdown. In addition, two other factors were also evident. Firstly, there was a Change in customer base (Fig. 1) in terms of visitor flows. And secondly, tourism service providers specifically mentioned examples of changes in visitor behavior. These examples were categorized (e.g., Ordering process, New segment, Missing demand). The word cloud (Fig. 2) below shows the frequency of responses (examples) in each category.

Figure 2 Changes in the behavior of visitors $(n=120)$

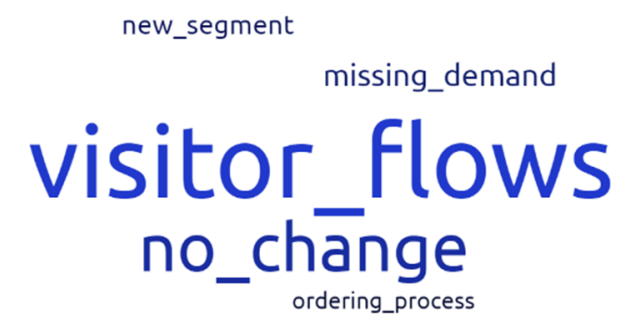

Source: own research

The change in visitor flows was experienced by $43 \%(n=120)$ of respondents. From the comments, four scenarios can be identified by respondents. The most common was a simultaneous decline in domestic and foreign demand (1). The second scenario was characteristic of the entire Czech Republic, specifically a decline in foreign visitors (2). The opposite of the second scenario was an increase in domestic visitors (3). The last scenario, less reported, is a combination of the second and third scenarios, where there was a simultaneous increase in domestic visitors and decrease in foreign ones (4). The same scenarios of the change in visitor flows were also confirmed by interview respondents. Logically, the decline in foreign visitors is due to the closure of national borders.

Concerning the change in visitor behavior, the results reveal that visitors came in smaller groups, i.e., where traditionally families with children came, couples started to come; where commercial events/conferences/training were commonly held, there was a demand for less capacity private events. Moreover, the findings indicate that there was a change in clientele in terms of income - 'wealthier' domestic visitors. In addition to the change in the segment of visitors, the ordering process and requirements changed (see Ordering process). There was an 
increase in demand for shorter stays (weekend stays). The volume of bookings in advance decreased and on the contrary, last minute, respectively just in time, demand increased. More online bookings were made.

\section{Reactions to the visitor's changed behavior - strategies}

Generally, the response of tourism service providers to the Change/adaptation to customer requirements was sorted out into five categories. The following word cloud below (Fig. 3) presents the frequency of responses in each category. Two exit strategies as a reaction to the changes caused by the COVID-19 pandemic in the first wave (spring 2020) are evident.

Figure 3 Reactions of tourism service providers $(n=120)$

\section{segment_stimulation}

\section{no_change sericessusension product_change}

Source: own research

The first (dominant) strategy can be described as latent according to the respondents' reactions ('no change'). This strategy is characterized by a lax approach to dealing with or adapting to a crisis situation. It is manifested at most by the introduction of hygiene measures ('safety'), which, however, stem from the obligation to accept government regulations rather than from the will of the respondents. The second option is an adaptation strategy. In this case, tourism service providers approached the crisis in a proactive manner. In addition to implementing hygiene measures, they showed their own willingness to optimize services ('product change') and/or to stimulate visitors ('segment stimulation').

The matrix of change (Tab. 3) shows the reactions of tourism service providers in relation to a specific change on the demand side, which was manifested by the COVID-19 pandemic. The matrix shows that $22.5 \%(\mathrm{n}=120)$ of respondents did not react to the changes in visitor behavior (see New segment $(n=2)$, Ordering process $(n=4)$, Visitor flows $(n=21)$ ) or even interrupted/terminated their service provision $(4 \% ; n=120)$. On the contrary, although some tourism service providers did not experience any change in demand, a few individuals $(n=7)$ still adjusted their offer. 
Table 3 Matrix of change $(n=120)$

\begin{tabular}{|c|c|c|c|c|c|c|}
\hline \multirow{17}{*}{ 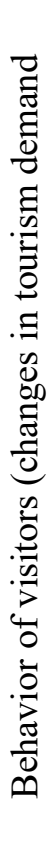 } & \multicolumn{6}{|c|}{ Reactions of tourism service providers (changes in tourism supply) } \\
\hline & & $\begin{array}{c}\text { No } \\
\text { change } \\
(47 \%)\end{array}$ & $\begin{array}{c}\text { Segment } \\
\text { stimulation } \\
(14 \%)\end{array}$ & $\begin{array}{l}\text { Product } \\
\text { change } \\
(29 \%)\end{array}$ & $\begin{array}{c}\text { Service } \\
\text { suspension } \\
(4 \%)\end{array}$ & $\begin{array}{c}\text { Safety } \\
(6 \%)\end{array}$ \\
\hline & No change $(28 \%)$ & 24 & 1 & 7 & 1 & 0 \\
\hline & Private sector & 21 & 1 & 4 & 1 & 0 \\
\hline & Public sector & 3 & 0 & 3 & 0 & 0 \\
\hline & New segment $(10 \%)$ & 2 & 2 & 6 & 0 & 2 \\
\hline & Private sector & 2 & 2 & 4 & 0 & 2 \\
\hline & Public sector & 0 & 0 & 2 & 0 & 0 \\
\hline & Missing demand (12\%) & 5 & 2 & 4 & 2 & 1 \\
\hline & Private sector & 4 & 2 & 3 & 0 & 1 \\
\hline & Public sector & 1 & 0 & 1 & 2 & 0 \\
\hline & Ordering process $(7 \%)$ & 4 & 3 & 3 & 0 & 0 \\
\hline & Private sector & 3 & 3 & 3 & 0 & 0 \\
\hline & Public sector & 1 & 0 & 0 & 0 & 0 \\
\hline & Visitor flows (43\%) & 21 & 9 & 15 & 2 & 4 \\
\hline & Private sector & 17 & 8 & 8 & 2 & 1 \\
\hline & Public sector & 4 & 1 & 7 & 0 & 3 \\
\hline
\end{tabular}

Source: own research

The most common reaction to the change in demand was the modification of their tourism service/product $(29 \% ; n=120)$. A quarter of tourism service providers responded to changes in visitor flows. Besides the change in their service/product $(n=15 ; 12.5 \%)$, they focused on the stimulation of their customers $(n=9 ; 7.5 \%)$. A key tool for them was pricing policy, i.e., lowering prices, providing discounts, and other incentives, such as free gifts when using the service.

Other interesting results on the corona crisis are offered by the perspective of business sector and public sector. While different strategies for dealing with the corona-crisis emerge for business service providers, which is mainly due to the fact that each tried to deal with a very atypical situation in its own way and to the best of its ability; for public service providers, a "new" trend emerged (not quite typical of the generally inflexible sector) in the form of moving their activities to the online space. The results of the interviews indicate that the reason for this strategy is the "additional" spare time and, above all, the need to stay in constant contact with visitors (see the new communication mix) - the so-called strategy "To be visible".

\section{Tourism service providers and government restrictions}

It is evident that thanks to the government restrictions, the vast majority of tourism service providers $(87 \% ; \mathrm{n}=121)$ experienced the Change of their revenues and only 14 respondents did not make a loss compared to the situation before the corona crisis. On average, tourism service providers' profits decreased by $25 \%$. A positive finding was that only one respondent 
stopped his/her business after the first wave of the COVID-19 pandemic (spring 2020). The verbal responses indicated that many private tourism service providers would not tolerate another lockdown, primarily due to the lack of funding. However, another good finding was that a very small percentage $(+/-8 \% ; \mathrm{n}=121)$ of respondents said they were struggling with debt and staff redundancies. The latter was largely a result of the large representation of family businesses with zero number of employees and simultaneous use of subsidy programs for supporting employment (Antivirus Program). The departure of employees was also not dramatic for tourism service providers, although the general concern of workers leaving the tourism sector was mentioned in the verbal comments. This was also confirmed by the respondents in the interviews.

Generally, tourism service providers managed to cope with the government restrictions even if the respondents' comments on the implemented government measures showed a strongly negative sentiment $(74 \% ; n=121)$. The categorized evaluative statements are described by the word cloud (Fig. 4). The most frequent statement (more than 1/3) was "no comment", meaning I prefer not to comment. The next most frequent statement was "chaos". Tourism service providers consider the governments restrictions "nonsense" and "tourism destructive".

Figure 4 Statements evaluating the government restrictions - word cloud $(n=121)$

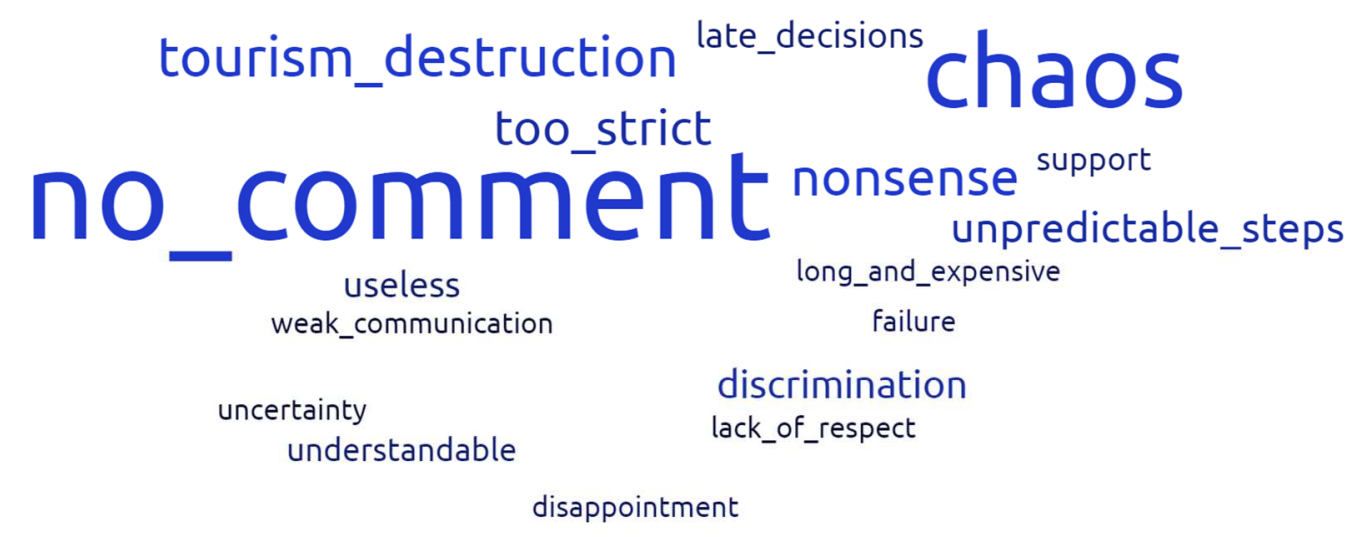

Source: own research

\section{DISCUSSION}

The visitor behavior has definitely changed. Although at first glance it may seem that the trend of 'cheaper, shorter and faster' holidays (Poon, 2003) is still continuing, the reality changed by the corona-crisis is different. The research results confirm that shorter stays are in demand, but their character differs. This result also confirms Huang, Shao, Zeng, Liu \& Li (2021) research. This is not a mass issue. According to the study published by Revfine.com (2020), trends related 
to the COVID-19 pandemic include, for example, safety and hygiene standards, emphasis on leisure (fewer business trips in comparison with leisure travelling), shift from international to local, and technology in tourism (contactless payments or booking via the Internet). All these mentioned trends independently confirm the results of this research. In the case study tourism service providers emphasized the change in the segment (the decrease of commercial events in favor of leisure clientele), as well as they proved the shift from international to local destinations. In addition, they realized the importance of information and communication technologies in tourism. Further mentioned trends in Revfine.com study cannot be verified because they are common for large (international) enterprises.

The reactions of respondents (tourism service providers) confirm that the COVID-19 pandemic represents an exogenous shock (Keller, 2020). In such a situation, support from the government is essential (Hall, Scott, \& Gössling, 2021), as proved by a study from Macao (McCarney, 2020). However, on the part of tourism service providers, this requires the adoption of the necessary strategy to help to overcome the crisis. Stressful situations bring with them pressure for greater creativity and new solutions, as confirmed by the respondents' comments. In the context of the impact of the corona crisis on the development of rural tourism, all is not as black as it seems. Richard (2020) highlights the pitfalls of large-capacity accommodation establishments that are based on socializing. In times of the pandemic, this poses a problem because the key government restriction to avoid the spread of coronavirus disease is done by the limitation of social contacts. In this context service providers in rural tourism have a certain "advantage".

\section{CONCLUSION}

This study provides the evidence of how tourism service providers in rural tourism managed to cope with the crisis situation that was caused by the COVID-19 pandemic. The crisis came unexpectedly and to adapt to it requires them considerable effort. The findings indicate that in rural tourism there are especially small-sized entrepreneurs and family businesses that are very sensitive to market changes. It is obvious that tourism service providers had to face the most complicated times in their lives. The findings of the case study in the South Moravia region revealed that at the beginning of the COVID-19 pandemic (spring 2020) tourism service providers had reacted in compliance with the government restrictions and at the same time they did very impulsively their best to survive the tough situation (without any previous experience). 
In their effort to cope with the crisis of the COVID-19 pandemic, they generally invented two types of exit strategies. The first one is the latent strategy with no or a little action, i.e. do nothing "("no change""'); limit the provided service "("service suspension""'); or fulfil the government restrictions "("safety"'"). On the contrary, the second strategy is proactive with a willingness to adapt to the situation (therefore adaptation strategy). Tourism service providers made an effort to optimize their service or modify it according to the customers" requirements "("product change""). Moreover, as a part of their strategy, they intensively stimulated their customers "("segment stimulation"'") and generally, they had to adapt their activities to the new patterns of visitor behavior (e.g., ordering process, communication mix in marketing). Especially the public service providers (i.e., DMOs and tourist centers) showed very a flexible reaction to the 'customers' needs and moved their activities online.

Despite the very negative assessment of government regulations, most tourism service providers fought for their existence and looked for ways to use this time for new ideas. Therefore, in the short term they changed/rethought their priorities and set their (adaptation) strategy on "'swift innovations"".

\section{Acknowledgement}

The paper was prepared within the Specific Research Project No. MUNI/A/1399/2020 of Masaryk University, Brno, Czech Republic.

\section{REFERENCES}

Arbulú, I., Razumova, M., Rey-Maquieira, J., \& Sastre, F. (2021). Can domestic tourism relieve the COVID-19 tourist industry crisis? The case of Spain. Journal of Destination Marketing \& Management, 1(20), 100568.

Antušák, E. (2009). Krizový management. Hrozby - krize - př́ležitosti. Praha: Wolters Kluwer.

Cohen, E. (1972). Towards a Sociology of International Tourism. Political Economics, 39(1), 164-182.

Fotiadis, A. Polyzos, S., \& Huan, T.C. (2021). The good, the bad and the ugly on COVID-19 tourism recovery. Annals of Tourism Research, 87, 103117.

Gössling, S., Scott, D., \& Hall, C. M., (2021). Pandemics, tourism and global change. A rapid assessment of COVID-19. Journal of sustainable tourism, 29(1), 1-20.

Hall, C. M., Scott, D., \& Gössling, S., (2020). Pandemics, transformations and tourism: be careful what you wish for. Tourism Geographies, 22(3), 577-598.

Hao, Y., Bai, H., \& Sun, S. (2021). How does COVID-19 affect tourism in terms of people' 's willingness to travel? Empirical evidence from China. Tourism Review, 76(4), 892-909.

Holešinská, A., \& Záboj, M. (2021). COVID-19, government's decisions and impacts on tourism businesses. In V. Klímová \& V. Žítek (Eds.), XXIV. mezinárodní kolokvium o regionálních vědách (230-236). Brno: Masarykova univerzita.

Huang, S., Shao, Y., Zeng, Y., Liu, X., \& Li, Z. (2021). Impacts of COVID-19 on Chinese nationals' tourism preferences. Tourism Management Perspectives, 40 (in progress). 
Keller, P., (2020). Corona pandemic as exogenous shock for international tourism: a context analysis. In F. Burini (Ed.), Tourism facing a pandemic: from crisis to recovery (pp. 1524). Bergamo: Universita degli Studi di Bergamo.

Kock, F., Nørfelt, A., Josiassen, A., Assaf, A. G., \& Tsionas, M. G., (2020). Understanding the COVID-19 tourist psyche: The Evolutionary Tourism Paradigm. Annals of Tourism Research, 85(Nov.), 103053.

Plog, S. C. (1974). Why destination areas rise and fall in popularity. Cornell Hotel and Restaurant Quarterly, February, 55-58.

Poon, A. (2003). Competitive strategies for a new tourism. In C. Cooper (Ed.), Classic Reviews in Tourism (pp. 131-142). Clevedon: Channel View.

Revfine.com (2020). Discover The Latest Trends in The Tourism Industry. [online report]. Retrieved from https://www.revfine.com/tourism-trends/.

Richards, G., (2020). The impact of crisis on travel: Covid-19 and other shocks. In F. Burini (Ed.), Tourism facing a pandemic: from crisis to recovery (pp. 25-31). Bergamo: Universita degli Studi di Bergamo.

Tajeddini, K., Ratten, V., \& Merkle, T. (2019). Tourism, Hospitality and Digital Transformation: Strategic Management Aspects. New York: Routledge.

Škare, M., Soriano, D. R., \& Porada-Rochoń, M., (2021). Impact of COVID-19 on the travel and tourism industry. Technological Forcasting \& Social Change, 163(February), 120469.

Urry, J. (1990). The Tourist Gaze: Leisure and Travel in Contemporary Society. London: SAGE.

WYSE Travel Confederation (2020). COVID-19 travel business impact series. March 2020. [online report]. Retrieved from https://www.wysetc.org/2020/03/covid-19-travelbusiness-impact-series-part-1/. 